\title{
THE INDONESIAN CLASSROOM MANAGEMENT (An Ethnographic Study of Indonesian Classroom Behavior)
}

\author{
Muhammad Fatkhu Arifin \\ Ahmad Dahlan University, Indonesia \\ upin19ipin@gmail.com
}

\begin{abstract}
This study entitled "The Indonesian Classroom Management. It is purposed to answer the problem formulation that questioning about how the Indonesian classroom behaves, how Indonesian classrom is managed by the teacher, and how the confortable classroom look like based on the students' perspective. This research used descriptive qualitative that describe the data that have been collected. The object of this study is the Indonesian classroom behaviour. The data were collected by observing the Indonesian classroom especially in English subject. The data collected were interpreted and described in the report. The result shows that Indonesian classroom has some behaviours such as; make a line before entering the class, praying before the class begin, singing the National Anthem, shaking the teachers' hands whether in the begining and closing of the class, asking permission when to leave the class just for washing hands, praying after finish the whole activities in a day. In can be concluded from the result that Indonesian classroom has a very polite and orderly.
\end{abstract}

Keywords: Indonesian classroom, classroom management, behaviour

\section{INTRODUCTION}

Classroom management is an educational aspect which is frequently used as the major concern by the prospective teachers, fresh teachers, even the experienced teachers. They-prospective teachers, fresh teachers, and the experienced teachers-are expecting that the students could learn optimally. It is in the terms of the capability of the teacher in delivering the knowledge to the students.

The creation of comfortable classroom is the concern of classroom management. For it is a series of teachers' behavior in their efforts to create and maintain classroom conditions that allow students to learn well.

Classroom is the place where all aspects of learning to meet and proceed; teachers with all their ability, students with all their background and potention, curriculum with all its' components, method with all its' approach, media with all its' devices, learning materials with all the source, those all meet and interact in the classroom. Meanwhile, the learning outcomes determined also everything that happens in the classroom. Therefore, it is proper that the classroom should be managed well, professional, and sustainable.

Further, classroom management is factually influenced by the cultural aspect. For instance, American classroom in United State of America that reflect the American cultural perspective. The cultural impact in American classroom can be seen from the way they behave in learning process which is typically ignoring the politeness. In American classroom behaviour, teachers frequently come earlier in the calss before the students. In other case, it is unnecessary for the students to ask teachers' permission when they want to leave the class in the need of nose poudering. Students are also allowed to bring snack and softdrink during the class. Those characteristics are in line with the American perspective which is tend to the liberation. 
Nowadays, the educational system in Indonesia seems like in the effort of adapting the American classroom management. However, each culture has different values, which has positive and negative sides. To apply one's culture to the other places may not always work well.

Further, the big difference between western and eastern culture should be the consideration in managing Indonesian classroom. As the example, leaving the class without asking teacher's permission is in contrast with the eastern values especially Indonesia which upholding the politeness to the elder and has a seniority perspective. Partially adoption to the better educational system might be acceptable, yet completely adoption is a mistake. We may learn from American, but we may not be American.

In conclussion, Indonesia as the independent nation must has its own classroom management which is suitable with the Indonesian culture. Partially conducting American classroom behaviour might be considered as long as it is not opposing the Naionalism values. This study is proposed to observe the Indonesian classroom behaviour in search of the most appropriate classroom management for the learning process.

\section{LITERATURE REVIEW}

2.1 Ethnographic Designs

Ethnographic designs are qualitative research procedures for describing, analyzing, and interpreting a culture-sharing group's shared patterns of behaviour, beliefs, and language that develop over time. Central to this definition is culture. It can include language, rituals, economic and political structures, life stages, interactions, and communication styles. To understand the patterns of a culturesharing group, the ethnographer typically spends considerable time in the field interviewing, observing, and gathering documents about the group to understand their culture-sharing behaviors, beliefs, and language. (Creswell, 2012)

Based on the creswell definition, ethnographic designs is the study of culturalgroup behaviors. It focus on exploring the detail activity in one group. Further, this kind of research design is appropriate with the study that is to learn about the Indonesian classroom behaviors.

\subsection{Realist Ethnographies}

A realist ethnography is a popular approach used by cultural anthropologists. Characterized by Van Maanen (1988), it refl ects a particular stance taken by the researcher toward the individuals being studied. A realist ethnography is an objective account of the situation, typically written in the third-person point of view, reporting objectively on the information learned from participants at a field site. In this ethnographic design:

a. The realist ethnographer narrates the study in a third-person dispassionate voice and reports on observations of participants and their views. The ethnographer does not offer personal refl ections in the research report and remains in the background as an omniscient reporter of the "facts."

b. The researcher reports objective data in a measured style uncontaminated by personal bias, political goals, and judgment. The researcher may provide mundane details of everyday life among the people studied. The ethnographer also uses standard categories for cultural description (e.g., family life, work life, social networks, and status systems). 
c. The ethnographer produces the participants' views through closely edited quotations and has the fi nal word on the interpretation and presentation of the culture (Van Maanen, 1988).

\subsection{Classroom Management}

The definition of class management based on Weber .W.A. (1988), defines the class as complex management of teaching behavior of teacher efficient instruction "which implies that all efforts are directed to creating an effective learning atmosphere and fun and motivating students to learn well. Eferstson and Emmer described management as "teacher behavior that produceshigh Reviews those levels of student infolfoment classroom activities and student behaviors that minimize and pencapaianthe interfiris with teachers or other students work and efficient use of instructional time. Houston et al (1988), asserts that "Without effective mamanagement the learning process student for interfering with instruction", which implies that without the effective management of the learning process becomes chaotic that teachers would reprimand students who menggagu learning process.

Arikunto, (2006) defines the classroom management is an effort undertaken in charge of teaching and learning what helps with the intention to achieve optimal conditions, so that it can be done and learning activities as expected. Muliyasa (2006) defines a classroom management skills of teachers to create a conducive learning environment and to manage them if there is disruption in learning.

Based on the views of certain operational approach (Excerpted from Wiford A. Weber, 1986) classroom management is a set of activities teachers to create and maintain order upscale atmosphere through the use of discipline (authoritarian approach), which consists of devices, namely (1) A set of activities teachers to create and maintain order upscale atmosphere through intimidation (bullying approach). (2) A set of activities to maximize the freedom of student teachers (permissive approach). (3) A set of activities teachers to create a classroom atmosphere by following the instructions / recipes that have been in the present (cook book approach). (4) A set of activities teachers to create a classroom atmosphere that is effective through planning quality learning and well executed (instructional approach). (5) A set of activities teachers to develop learners' behavior desired by reducing unwanted behavior (approach to changing behavior). (6) A set of activities teachers to develop good interpersonal relationships and socio-emotional climate positive classroom (socioemotional climate creation approach). (7) A set of activities of teachers to foster and maintain an effective class organization (social system approach) Arikunto, (2006).

\section{METHODS}

\subsection{Research Approach}

The research approach is the qualitative approach. According to Hancock, et al., (2009) qualitative research is concerned with developing explanations of socialphenomena.That is to say, it aims to help us to understand the social world in which we live and why things are the way they are. Hancock believe that It is concerned with the social aspects of our world and seeks to answer questions about:

a. Why people behave the way they do.

b. How opinions and attitudes are formed.

c. How people are affected by the events that go on around them.

d. How and why cultures and practices have developed in the way they have.

In line with Hancock, Sarwono (2006) provided the urgencies of using qualitative approach to research if the concerned want to do the following things: 
a. Understand the underlying meaning of the behavior of participants.

b. Describe the background and partisan interaction.

c. Exploration to identify new information.

d. Understand the limited circumstances and would like to know in depth and detail.

e. Describe the phenomenon to create a new theory.

f. Focusing on human interaction and processes they use.

In other words, qualitative research attempts to broaden and/or deepen our understanding of how things came to be the way they are in our social world. If the research question involves exploring how people experience something, or what their views are, exploring a new area where issues are not yet understood or properly identified (e.g. before developing questionnaire items), assessing whether a new service is implementable, looking at 'real-life' context, or a sensitive topic where the researcher need flexibility to avoid causing distress, so it is closely necessary to apply qualitative research (Hancock, et al., 2009).

The above explanation shows some keywords in qualitative research, namely: processes, understanding, complexity, interaction, and human. The process of doing research is the emphasis on qualitative research therefore in carrying out the study, researchers focused more on the process rather than the end result. The process in this research requires time and conditions that changing, than the definition of this study will have an impact on the design of the study and ways to implement them that also changing or is flexible.

Therefore, researcher believes that the qualitative research is concidered more appropriate toward this study -analyzing the illocutionary act. This believe is in line with Hancock, et al., (2009) that qualitative research is concerned with developing explanations of social phenomena. That is to say, it aims to help us to understand the social world in which we live and why things are the way they are.

Further, researcher sees that the video entitled "The Meaning of Life" publishe by Talk Islam is consisting some utterances that included of speech act. It means that the human behaviours and interactions are mightly existed in the video. So that the researcher needs to explore the social impact which is brought by the publisher in making the video. It is also related to the action in saying words as the basis of speech act.

Seeing the explanation above, the researcher applying the qualitative approach in order to discover point of view in the video. The researcher use discourse analysis in exploring the utterances' meaning and interpretation consisted in the video entitled "The Meaning of Life" by Talk Islam.

\subsection{Data Collecting Technique}

The technique of collecting data that is used in this research is observation. Based on Hancock, et al., (2009), observation is a technique that can be used when data cannot be collected through other means, or those collected through other means are of limited value or are difficult to validate. In some research observation of people is not required but observation of the environment. This can provide valuable background information about the environment where a research project is being undertaken.

In this study, researcher uses observaion as the data collecting technique. It is conducted by observing the Indonesian classroom during the learning process in one semester. Researcher may take some interview or documentation in order to enrice the accuracy of the data. 


\subsection{Data Analysis Technique}

According to Hancock, et al., (2009), data analysis involves processing or summarising the mass of the data collected then pesent the most important features. Hancock and friends added that in qualitative research, the practice of data analyzing is such describing the phenomenon, articulating what it means, and understanding it. While in this research, the researcher applying all the implementations that are mentioned by Hancock.

The researcher describes and analyze the data cillected by observing the Indonesian classroom and make interpretation about the patterns seen and heard. During data collection, the researcher begins to forge a study. This consists of analyzing the data for a description of both the individuals and sites of Indonesian classroom; analyzing patterns of behavior, beliefs, and language; and reaching some conclusions about the meaning learned from studying the people and sites.

\subsection{Data Reporting Technique}

Hancock, et al., (2009) stated the data reporting technique as the story of how the researcher undertook the analytical process forms the basis of the presentation. They also underlined that the objective of the data reporting is communication and sothe presentation should be tailored to suit the audience. In short, data reporting technique is used to communicate the result of the research.

Ethnographic researchers make interpretations and write their report reflexively. Reflexivity in this research refers to the researcher being aware of and openly discussing the role in the study in a way that honors and respects the site and participants. Because ethnographic research involves a prolonged stay at a site, researcher is concerned about the impact on the site and the people. The researcher negotiates entry with key individual and plan to leave the site as undisturbed as the researcher found it. As individual who has a history and a cultural background, the researcher realizes that the interpretation is only one possibility, and that the report does not have any privileged authority over other interpretations made by readers, participants, and other researchers.

\section{FINDINGS AND DISCUSSION}

From the observation of the Indonesian classroom, the researcher found that there are some behaviours as follow;

a. Make a line

The rules of Indonesian classroom require the students to make a line before entering the class. It aims to teach discipline to the students. It can be seen that the students enter the classroom in an orderly manner.

b. Praying

Before the class begin, the students are invited to having a pray according to their beliefs. Indonesia is the religious Nation that giving priority to the religious aspect. Praying before begining study is a habit that is hereditary in education.

c. Singing The National Anthem

In order to build the students' Nationality, singing the National Anthem becomes one of the requirement before starting the class. This is applied only in the firs hour of the school activities. The class has five up to ten minutes to sing the National Anthem.

d. Shaking Teachers' Hands

The students in Indonesian classroom are used to shake the teachers' hand whether in the begining and in the last hour of the school activities. This habit 
shows the politeness culture of Indonesian people. Besides, it is also the ethic code of the students toward their teachers.

e. Asking Permission

When students need to leave the class for washing hands of other emergency matters, they are used to seeking a permission to the teacher. It is maight be different with the classroom behaviour in other Nations. As the example, in American classroom, the students do not need to asking the permission when they have to leave the class for such reasons.

Those are five major notes that have been collected during the observation. From those major points, it can be seen that the politeness has been conducted in the school. The researcher argue that those points should be seen as the excellences of Indonesian classroom from other classroom behaviour-such as American classroom behaviour.

\section{CONCLUSION AND SUGGESTION}

From the result of the study, the researcher conclude that there are at least five major points that become the characteristic of Indonesian classroom, those are; make a line before entering the class, praying before the class begin, singing the National Anthem, shaking the teachers' hands whether in the begining and closing of the class, asking permission when to leave the class just for washing hands, praying after finish the whole activities in a day. Those points represent the culture and the character of Indonesian people. The politeness and order are strongly shown in the behaviour of Indonesian classroom behaviour.

As the suggestion, Indonesian classroom with the five major points of behaviour above is more applicable for Indonesian learning process. It does not matter to learn from other Nations' behaviour, but it is not acceptable to become like them. It is strongly recomended in Indonesian ELT. What happen nowadays is that Indonesian students learning English in order to be like British. It considered that western culture is different with eastern. So the perspective of ELT students should 'learn about them', not 'learn to be like them'.

\section{REFERENCES}

Arikunto, S. (2006). Prosedur Penelitian: Suatu Pendekatan Praktik. Jakarta: Rineka Cipta.

Creswell, J. W. (2012). Educational Research : Planning, Conducting, and Evaluating Quantitative and Qualitative Research. Boston: Pearson Education, Inc.

Hancock, B., \& Ockleford, E. a. (2009). An Introduction to Qualitative Research. Nottingham: The NIHR RDS for the East Midlands.

Maanen, J. V. (1988). Tales of the Field: On Writing Ethnography. Chicago: University of Chicago Press.

Mulyasa, E. (2006). Menjadi Guru Profesional Menciptakan Pembelajaran. Bandung: Remaja Rosdakarya Offset.

Sarwono, J. (2006). Metode Penelitian Kuantitatif dan Kualitatif. Yogyakarta: Graha Ilmu. 